\title{
Lipid Synthesis and Secretion by Primary Cultures of Rat Mammary Epithelial Cells
}

\author{
ELIZABETH M. ROHLFS, DEXTER S. LOUIE, AND STEVEN H. ZEISEL* \\ Department of Nutrition CB \#7400, School of Public Health and School of Medicine, \\ University of North Carolina at Chapel Hill, Chapel Hill, NC 27599-7400
}

\begin{abstract}
Lipid synthesis and secretion was measured in primary rat mammary epithelial cells cultured on basement matrix in medium supplemented with lactogenic hormones. The cells grew and differentiated to form alveolar-like structures reminiscent of lactating mammary gland. They synthesized abundant triacylglycerol, containing fatty acids characteristic of rat milk (C10:0-C14:0), using ${ }^{14} \mathrm{C}$-glucose, ${ }^{14} \mathrm{C}$-oleic acid or ${ }^{14} \mathrm{C}$-glycerol as precursors. Basal levels of triacylglycerol secretion were measured using ${ }^{14} \mathrm{C}$-oleic acid labeling; $1.3 \pm 0.3 \%$ of the labeled cellular triacylglycerol was secreted into the medium in 24 hours. Secreted lipid droplets were surrounded by a bilayer membrane with an electron-dense inner coat characteristic of fat globules secreted by the mammary gland. The rate of triglycerol secretion was increased to $998 \pm 98 \%$ of control $(P<0.01)$ by the addition of phorbol 12-myristate 13-acetate (PMA) in combination with staurosporine, a protein kinase inhibitor. Several other protein kinase inhibitors, when combined with PMA, also markedly stimulated secretion. Effective protein kinase inhibitors included sphingosine (has diverse cellular effects including the inhibition of protein kinase C; 13-fold increase in secretion), and KT5823 (a CGMP dependent protein kinase inhibitor; 5-fold increase). KT5720 (a cAMP-dependent protein kinase inhibitor) did not alter secretion. Kinase inhibitors were effective only in the presence of a phorbol ester. $4 \alpha$-phorbol-12,13-didecanoate, a phorbol ester which does not activate protein kinase $C$ (PKC), could substitute for PMA. Lipid release was not mediated by disruption of cell-cell tight junctions, as EGTA did not release lipid. Based on these observations we suggest that two signals are needed to enable or stimulate lipid secretion in cultured rat mammary epithelial cells: 1) inhibition of a protein kinase and 2) a PKC-independent effect of phorbol ester. We have, for the first time, characterized a cell culture model suitable for studying lipid synthesis and secretion by mammary epithelial cells.

(c) 1993 Wiley-Liss, Inc.
\end{abstract}

Milk lipid is secreted from the lactating mammary gland by a unique process in which triacylglycerol droplets are extruded from the cell and coated by a bilayer membrane derived from the plasma membrane (Wooding, 1971a). The triacylglycerol core is surrounded by three layers: 1) a thin coat of cytoplasm (Wooding, 1971b), 2) an electron dense layer (inner coat material) tightly joined to a bilayer membrane (Freudenstein, et al., 1979; Jarasch, et al., 1977) and 3) glycocalyx (Bucheim, et al., 1988). The transition from an immature gland to a lactating gland is modulated by hormonal factors in the rat. The combination of prolactin, insulin and glucocorticoid stimulate lipogenesis (Cameron, et al., 1983), casein synthesis (Cameron and Rillema, 1983), and lactose synthesis (Collier, et al., 1977). Approximately 24 hours prior to parturition casein and lipid begin to accumulate within the cells. Decreased progesterone levels allow the full lactogenic effect of prolactin to be manifested, and by 8 hours prior to parturition casein and lipids have been secreted into the milk duct (Bartholomeusz, et al., 1976; Chatterton, et al., 1975).

The mechanism for the apposition of the lipid droplet to the bilayer membrane and the intracellular signal which initiates secretion are not known. Investigation of this process has been hampered by the lack of a suitable cell culture model which secretes milk lipids. The following studies characterize a cell culture model capable of lipid synthesis and secretion.

\section{MATERIALS AND METHODS Animals}

Immature virgin female Sprague-Dawley rats (Charles River Breeding Laboratories, Raleigh, NC) weighing 175 to 200 grams and approximately 60 days of age were used as a source of mammary tissue for cell culture experiments. Lactating female Sprague-Dawley rats weighing $325-350$ grams were used as a source of mammary tissue for the electron microscopy study on day 12 post-partum and for milk collection on day 15 post-partum. Animals were offered food (Agway rat chow, Granville Milling, Creedmoor, NC) and water ad libitum.

Received, February 3, 1993; accepted July 9, 1993.

*To whom reprint requests/correspondence should be addressed. 


\section{Mammary epithelial cell isolation}

Rats were lightly anesthetized with ether and mammary tissue collected. They were sacrificed by continued exposure to ether. Mammary epithelial cells were isolated using the method of Hahm and colleagues (Hahm and Ip, 1990; Hahm, et al., 1990). Briefly, the inguinal glands were digested in medium containing collagenase, dispase, fetal bovine serum, and gentamicin. Following digestion, organoids (remnants of mammary alveoli) were isolated by centrifugation and filtration. Stromal contaminants were removed during a short-term period (4 hours) in culture as they readily attached to the plates.

The isolated cells were counted by diluting $1 \mathrm{ml}$ of the organoid suspension in $7 \mathrm{ml}$ of $0.1 \mathrm{M}$ citric acid and incubating at $37^{\circ} \mathrm{C}$ for 1.5 hours (Hahm, et al., 1990; Sanford, et al., 1950). This procedure yields cell nuclei which were collected by centrifugation at $2500 \times \mathrm{g}$ for 10 minutes and resuspended in $1 \mathrm{ml}$ phosphate buffered saline (PBS). One hundred microliters of the nuclei suspension and $50 \mu \mathrm{l}$ of trypan blue $(0.4 \%$ in $0.85 \%$ saline, GIBCO) were combined and the nuclei counted in a hemacytometer. Our cell isolation procedure yielded approximately $3 \times 10^{6}$ cells/g tissue.

\section{Cell culture}

Organoids were suspended in a lactogenic medium formulation developed by $\mathrm{Hahm}$ and colleagues ( $\mathrm{Hahm}$ and Ip, 1990; Hahm, et al., 1990) with some modifications. Unattached mammary organoids were collected, washed once with growth medium and plated at a density of $2.5 \times 10^{5}$ cells/well in a $16 \mathrm{~mm}$ tissue culture well coated with $150 \mu l$ of Engelbreth-Holm-Swarm (EHS) tumor basement membrane matrix $(4.1-4.5 \mathrm{mg}$ protein $/ \mathrm{ml}$ ) diluted $1: 2(\mathrm{v} / \mathrm{v})$ with growth medium. The EHS matrix was allowed to gel for 4 hours at $37^{\circ} \mathrm{C}$ before the cell suspension was added. EHS was prepared as described by Hahm and Ip (Hahm and Ip, 1990, Hahm, et al., 1990) and Kleinman et al. (Kleinman, et al., 1986) with slight modifications. The EHS sarcoma was a generous gift of Dr. Hynda Kleinman, Laboratory of Developmental Biology and Anomalies, National Institute of Dental Research, National Institutes of Health, Bethesda, MD. The tumor was carried in male Swiss Webster mice (Charles River Breeding Laboratories) and passaged when it was approximately $3 \mathrm{~cm}$ in diameter. Our modifications in the method for EHS preparation included the addition of $150 \mu \mathrm{l}$ of $0.04 \%$ DNAase (Sigma Chemicals, St. Louis, MO) to the $24,000 \times \mathrm{g}$ supernatants prior to dialysis of the final extract. The resulting matrix was transferred to sterile $15 \mathrm{ml}$ tubes and stored at $-80^{\circ} \mathrm{C}$. Sterility was determined before use by plating the matrix with DMEM/ F12 for 72 hours at $37^{\circ} \mathrm{C}$ and checking for the growth of bacteria. The EHS matrix contained DNA as it is derived from a tumor. However, after the addition of DNAase and incubation at $37^{\circ} \mathrm{C}$, insignificant DNA was present.

The growth medium contained DMEM/F12 (1:1) (phenol red free) with $10 \mu \mathrm{g} / \mathrm{ml}$ bovine pancreas insulin, $1 \mu \mathrm{g} / \mathrm{ml}$ progesterone (dissolved in $100 \%$ ethanol and added to the medium with stirring; final ethanol concentration $=0.005 \%$; progesterone was removed from media just before the start of secretion studies so as to simulate the drop in progesterone that occurs at parturition), $1 \mu \mathrm{g} / \mathrm{ml}$ hydrocortisone, $5 \mu \mathrm{g} / \mathrm{ml}$ human transferrin, $10 \mathrm{ng} / \mathrm{ml}$ mouse epidermal growth factor, culture grade, (UBI, Lake Placid, NY), $1 \mu \mathrm{g} / \mathrm{ml}$ ovine prolactin, $5 \mu \mathrm{M}$ ascorbic acid, $1 \mathrm{mg} / \mathrm{ml}$ fatty acid-free bovine serum albumin (BSA), $50 \mu \mathrm{g} / \mathrm{ml}$ gentamicin, $16.5 \mu \mathrm{M}$ linoleic acid, and 7.14 $\mu \mathrm{M}$ linolenic acid. Linolenic acid in $100 \%$ ethanol was added to a beaker and dried under nitrogen, and the sodium salt of linoleic acid, $1 \mathrm{~g}$ BSA and $50 \mathrm{ml}$ DMEM/F12 were added to the same beaker and stirred at $4^{\circ} \mathrm{C}$ overnight. This formed a fatty-acid albumin complex which was used to make 1 $\mathrm{L}$ of growth medium. All supplements, unless otherwise noted, were obtained from Sigma.

When the cells were plated, the dishes were gently agitated by hand to disperse the cells evenly on the plate. If the cells are not dispersed, their growth and morphological development are limited. The medium was changed three times per week. When the cells were grown without essential fatty acids, neither linolenic nor linoleic acid were added to the medium. DMEM/F12 contains $0.042 \mathrm{mg}$ linoleic acid/L of medium. This is less than $1 \%$ of that in the supplemented medium.

\section{Staining with anti-epithelial membrane antigen}

Mammary epithelial cells were grown on a glass cover slip coated with EHS for 14 days. The cover slip was washed in PBS, $\mathrm{pH}$ 7.4, fixed in acetone for 10 minutes and incubated in the dark at $4^{\circ} \mathrm{C}$ for 4 hours with fluorescein isothiocyanate isomer (FITC) 1-conjugated monoclonal mouse anti-epithelial membrane antigen at a dilution of 1:25 (DakoPatts, Carpinteria, CA). The immunogen was human delipidated extract of milk fat globule membrane protein. The antibody reacts strongly with normal epithelium, in particular mammary epithelium, breast carcinoma metastases, and some adenocarcinomas (Cordell, et al., 1985; Heyderman, et al., 1985). After staining, the cover slip was washed 3 times in PBS and mounted on a slide using Gel/Mount (Biomeda Corp., Foster City, CA). The slides were viewed on a Leitz Orthomat 2 microscope and photographs taken with a Leitz Orthomat E camera. Negative controls included incubation of the mammary cells without antibody, to correct for autofluorescence, and incubation of CWSV-1 cells (SV40 immortalized hepatocytes; the generous gift of Dr. Harriet Isom, Penn State University) with antibody to correct for non-specific binding.

\section{Oil red $O$ staining}

Cells were fixed in $4 \%$ formaldehyde for 5 minutes, rinsed with distilled water for 2 minutes and dehydrated in $100 \%$ anhydrous ethylene glycol for 3 to 5 minutes. They were stained with $1.0 \%$ oil red $O$ in ethylene glycol solution for 2 to 3 minutes, rinsed quickly with $85 \%$ ethylene glycol, and then with distilled water for 3 minutes.

\section{Photography}

All phase contrast photographs of cultures were taken with a Nikon N6006 camera mounted on a Nikon Diaphot TMA phase contrast inverted microscope. 


\section{Processing of tissue and cells for electron microscopy}

Lactating mammary tissue, collected from lightly ether-anesthetized rats, was fixed for 3 hours in buffer containing $2.5 \%$ glutaraldehyde, $2 \%$ paraformaldehyde and $0.1 \mathrm{M}$ sodium cacodylate, $\mathrm{pH}$ 7.4. The specimen was rinsed with $0.1 \mathrm{M}$ sodium cacodylate buffer, post-fixed in $2 \%$ buffered osmium tetroxide for 1 hour, dehydrated through a series of ethanol concentrations $(50 \%, 70 \%$, $95 \%$, and $100 \%$ ), washed twice with acetone and embedded in Medcast resin. Sections were collected on 200 mesh copper grids, stained with uranyl acetate and lead citrate, examined and photographed on a Philips CM12 electron microscope operated at $80 \mathrm{kV}$. Mammary epithelial cells grown for 14 days on EHS matrix in the presence of lactogenic hormones were fixed and processed using the same procedure.

\section{Milk collection}

Lactating Sprague-Dawley rats were lightly anesthetized with ether and injected subcutaneously with oxytocin (LyphoMed, Inc., Rosemont, IL) at a dose of 2 $\mathrm{U}$ per $200 \mathrm{~g}$ body weight. Milk was collected by manual expression and the milk triglycerides isolated and analyzed for fatty acid content.

\section{Radiolabeling of cell metabolites}

On day 12 of mammary epithelial cell culture, the medium was supplemented with the unlabeled precursor (D-glucose, glycerol, oleic acid; Sigma) at a concentration equal to that of the radioactive precursor to be added so as to minimize perturbations occurring on the day that radiolabel incorporation was to be studied. On day 14 the medium was changed so that it contained the radiolabeled precursor: $\mathrm{D}-\left[2-{ }^{14} \mathrm{C}\right]$ glucose $(45 \mathrm{mCi} /$ mmol; New England Nuclear, Boston, MA), $\left[\mathrm{U}-^{14} \mathrm{C}\right]$ glycerol $\left(44 \mathrm{mCi} / \mathrm{mmol}\right.$; ICN, Irvine, CA), or $\left[1-{ }^{14} \mathrm{C}\right]$ oleic acid $(50 \mathrm{mCi} / \mathrm{mmol}$; ICN) at a concentration of 1 $\mu \mathrm{Ci} / \mathrm{well} / \mathrm{ml}$ of basal lactogenic medium. The incubation was continued for the designated time and the cells and medium collected. Samples were extracted by the method of Bligh and Dyer (1959) and the neutral lipids separated by thin layer chromatography (TLC) on silica-gel plates (Si250-PA; J.T. Baker Co., Philipsburg, $\mathrm{NJ}$ ), developed with hexane/ethyl ether/acetic acid $(50: 50: 1, \mathrm{v} / \mathrm{v})$ and visualized by exposure to iodine vapor. The individual phospholipids were also separated by TLC (chloroform/acetone/methanol/acetic acid/water; 30:40:10:10:5, v/v) and visualized by exposure to iodine vapor. Aqueous soluble compounds were separated by TLC (butanol/ethanol/water; $50: 32: 9$, v/v) and visualized by spraying with ethanolic sulfuric acid and heating to $120^{\circ}$ (Lewis and Smith, 1969). Radioactivity was quantified using a radiometric imaging scanner (Bioscan, Washington, D.C.) with the location of the various metabolites determined by external unlabeled standards (oleic acid; monopalmitoyl-glycerol; diolein; triolein; phosphatidylcholine, dioleoyl; Sigma). Data are expressed per $\mu \mathrm{g}$ DNA determined from adjacent wells of an alternating sequence.

\section{Lipid secretion}

Cells, in culture for 14 days, were incubated in the presence of $20 \mu \mathrm{M}(1 \mu \mathrm{Ci})\left[1-{ }^{14} \mathrm{C}\right]$ oleic acid $(50 \mathrm{mCi} /$ mmol) in basal lactogenic medium (without progesterone) for 4 hours. The medium was removed, the cells washed two times with PBS ( $\mathrm{pH} 7.4$ ) and the stimulating medium, which consisted of basal lactogenic medium with $20 \mu \mathrm{M}$ oleic acid (no radiolabel) and indicated potential stimulators, was added. After 24 hours, fresh medium was added and the stimulation continued. Forty-eight hours later, the medium was collected again and pooled with the 24 hour sample. The cells were also collected. The cells and medium were analyzed for triglyceride and phosphatidylcholine was described above. Data are expressed as percent of control to normalize for variation between individual experiments.

\section{Medium supplements tested for ability to stimulate lipid secretion}

Ovine prolactin, progesterone, L-thyroxin, $17 \beta$-estradiol, cholera toxin, $\mathrm{N}^{6}, 2^{\prime}$-O-dibutyryladenosine $3^{\prime}: 5^{\prime}$ cyclic monophosphate; carbamylcholine chloride, staurosporine, phorbol 12-myristate 13 -acetate, $4 \alpha$-phorbol 12,13 didecanoate, choline, linolenic acid, and linoleic acid were all purchased from Sigma Chemicals. EGTA was purchased from Kodak (Rochester, NY). Calphostin C, KT5823 and KT5720 were purchased from Kamiya Biomedical, Thousand Oaks, CA. Bovine pituitary extract was purchased from UBI, Lake Placid, NY. 4 $\alpha$-phorbol 12,13 didecanoate was also purchased from Calbiochem, La Jolla, CA as was D-erythyro-spingosine from bovine brain. These compounds were dissolved in water, ethanol or dimethylsulfoxide (DMSO; Mallinckrodt, St. Louis, MO), depending on their solubility, and diluted to the working concentration in medium just prior to use. The concentration of DMSO never exceeded $0.01 \%$ and the concentration of ethanol never exceeded $0.1 \%$. The control group always included the appropriate carrier. To determine whether phorbol ester and staurosporine disrupted intercellular junctions in a manner similar to that described for EGTA (Barcellos-Hoff, et al., 1989) we treated cells with $2.5 \mathrm{mM}$ EGTA (in calcium free-DMEM medium prepared in the same manner as the regular culture medium; Gibco), or with staurosporine $(20 \mathrm{nM})$ and phorbol 12-myristate 13 -acetate $(0.25 \mu \mathrm{M})$ in culture medium, for $10 \mathrm{~min}$ at $37^{\circ} \mathrm{C}$ followed by medium containing the treatment (EGTA $1.2 \mathrm{mM}$, or staurosporine $(20 \mathrm{nM})$ and phorbol 12 -myristate 13 -acetate $(0.25 \mu \mathrm{M})$ ) and $1 \%$ trypan blue. After 15 minutes at room temperature, the dye solution was replaced with fresh medium and cultures were examined for blue staining. In parallel experiments trypan blue was omitted, and triacylglycerol secretion was measured at timed intervals.

\section{MTT assay for cell viability}

Cell viability was assessed using the properties of 3-(4,5-dimethylthiazol-2-yl)-2,5-diphenyltetrazolium bromide (MTT; Sigma). MTT is a water soluble compound which enters cells and is converted to water insoluble MTT formazan by mitochondrial dehydrogenases of living cells (Carmichael, et al., 1987). Following a 72 hour treatment with stimulators, one mg MTT, or $200 \mu \mathrm{l}$ of a $5 \mathrm{mg} / \mathrm{ml}$ PBS stock, was added to each well containing $1 \mathrm{ml}$ of medium. The cells were incubated at $37^{\circ} \mathrm{C}$ for 4 hours, the medium was removed and the well 


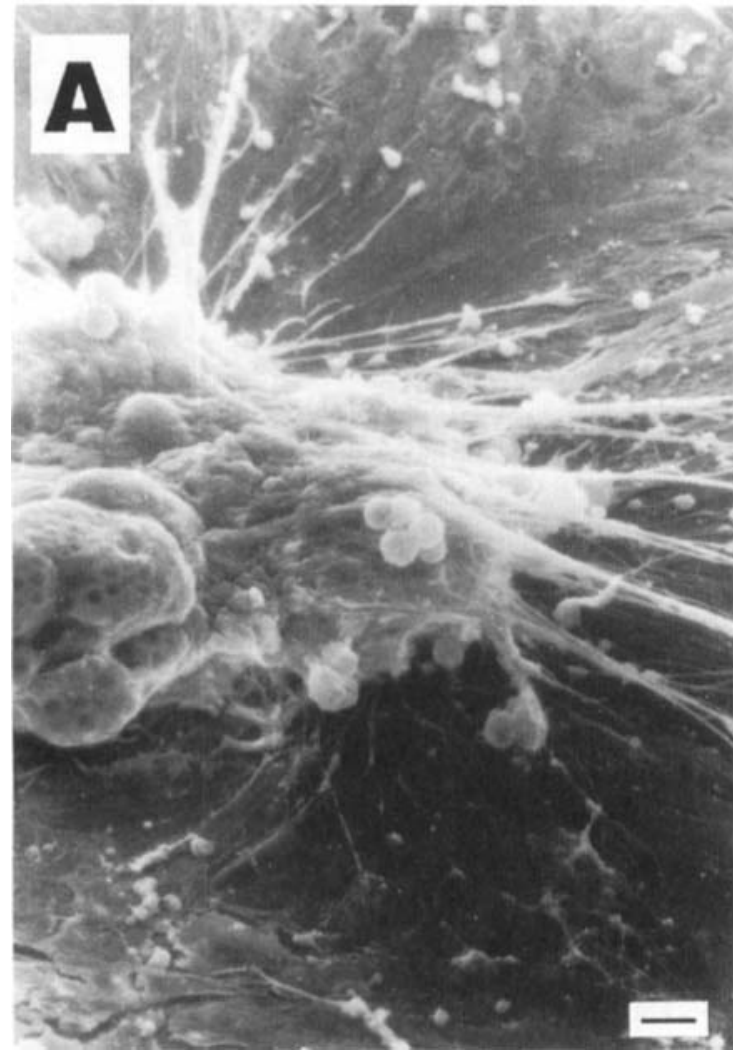

Fig. 1. Mammmary epithelial cells in culture. Mammary epithelial cells isolated from 60 day old virgin Sprague-Dawley rats were grown on EHS matrix in the presence of lactogenic hormones for 14 days. They developed alveolar and duct like structures and accumulated

washed with $1 \mathrm{ml}$ PBS. The cells were scraped from the well in $1 \mathrm{ml}$ PBS and centrifuged at $4500 \times \mathrm{g}$ for 15 minutes. The supernatant was aspirated and the pellet dissolved in $2 \mathrm{ml}$ DMSO. Absorbance was read at 570 $\mathrm{nm}$ in a LKB Ultrospec 4050 spectrophotometer. The data are expressed as absorbance/ $\mu \mathrm{g}$ DNA. The DNA values were obtained from adjacent wells in an alternating sequence treated with stimulators for 72 hours.

\section{Triglyceride assay}

Lipids, which were extracted and isolated as described earlier, were hydrolyzed in methanolic- $\mathrm{NaOH}$ to yield free fatty acid methyl esters. Triheptadecanoin (NuChek Prep, Alysian, MN) was added as an internal standard. Fatty acid methyl esters were measured by capillary gas chromatography (fused silica capillary column, $30 \mathrm{~m} \times 0.25 \mathrm{~mm}$ ) on a Perkin Elmer Sigma 2000 (Tacconi and Wurtman, 1985).

\section{Free fatty acid assay}

Lipids were extracted and isolated as described earlier. Heptadecanoic acid (NuChek Prep) was added as an internal standard. Fatty acids were converted to their methyl esters and measured as described earlier (Kishimoto and Hoshi, 1972; Tacconi and Wurtman, 1985).

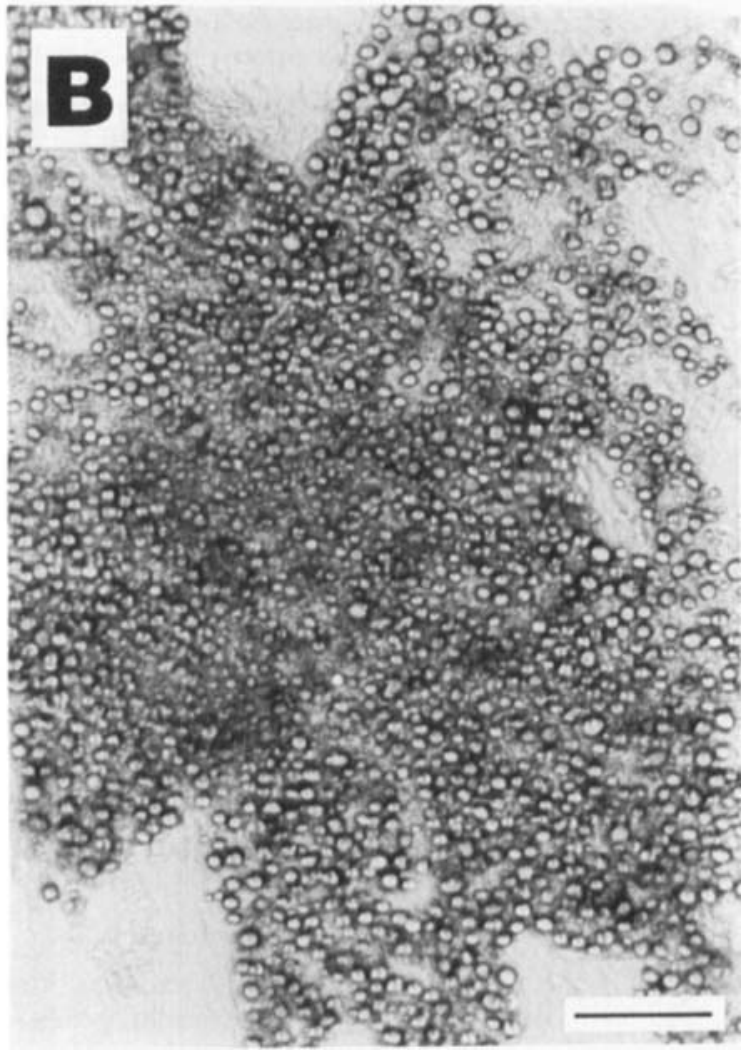

lipids. A) scanning EM of mammary alveolar structure on day 14 ; B) light microscopy of day 14 cells fixed in $4 \%$ formaldehyde, dehydrated in $100 \%$ anhydrous ethylene glycol and stained with oil red $O$ to demonstrate intracellular lipid. scale bars $=20 \mu \mathrm{m}$.

\section{Glycerol assay}

Cell glycerol was extracted by the method of Bligh and Dyer (1959) and assayed using Sigma Kit \#339 (Sigma). Briefly, glycerol was phosphorylated then oxidized to dihydroxyacetone phosphate and hydrogen peroxide. A quinoneimine dye was produced by the peroxidase catalyzed coupling of 4-aminoantipyrine and sodium N-ethyl-N-[3-sulfopropyl]m-anisidine. The absorbance of the colored reaction product at $540 \mathrm{~nm}$ was proportional to glycerol concentration. A standard curve was developed using free glycerol (Sigma).

\section{DNA assay}

DNA was quantified using the fluorochrome Hoechst 33258 (Sigma; Labarca and Paigen, 1980). Cells were collected from the dish by scraping into a $0.05 \mathrm{M}$ phosphate- $2 \mathrm{M} \mathrm{NaCl}$ buffer, $\mathrm{pH} 7.4$, sonicated by pulsing at output $4,30 \%$ duty cycle (Sonicator-Cell Disrupter, Heat Systems-Ultrasonics, Plainview, NY) and combined with the fluorochrome. The fluorescence was measured at excitation $356 \mathrm{~nm} / \mathrm{emission} 456 \mathrm{~nm}$.

\section{Statistical analysis}

Data was analyzed using one-way analysis of variance, with Scheffé's critical difference test, (Statworks for the Macintosh) or two-way analysis of variance and 


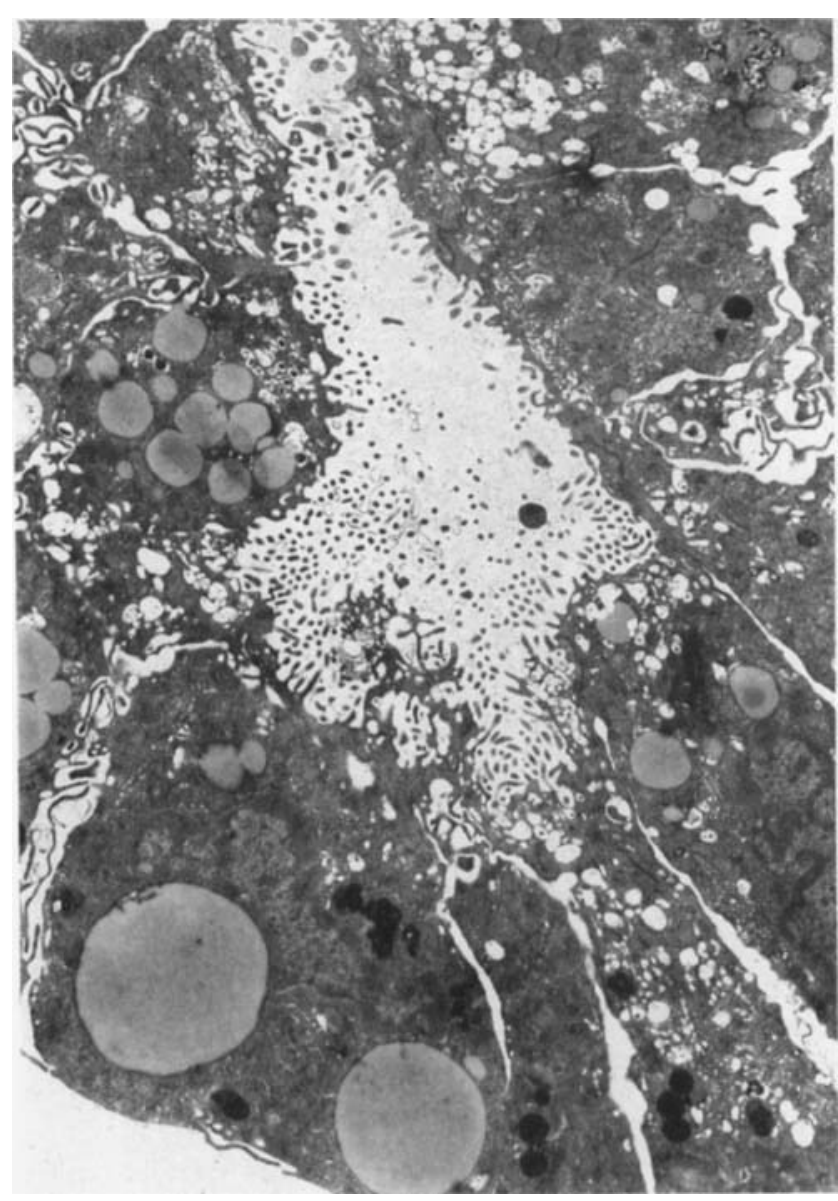

Fig. 2. Mammary epithelial cells in culture. Mammary epithelial cells were grown for 14 days as described in Fig. 1. Tissue was processed for electron microscopy as described in Methods. Note that epithelial cells are arranged with their apices (as indicated by microvilli) facing a central lumen. Note intracellular fat droplets and casein vesicles.

TABLE 1. Triacylglycerol content of mammary epithelial cells in culture

\begin{tabular}{llc} 
& \multicolumn{2}{c}{ nmol per $\mu \mathrm{g}$ DNA } \\
\cline { 2 - 3 } Days in culture & With EFA & Without EFA \\
\hline 0 & $0.2 \pm 0.02$ & $0.2 \pm 0.02$ \\
7 & $1.2 \pm 0.1$ & $0.7 \pm 0.1$ \\
14 & $3.8 \pm 0.5^{2}$ & $5.9 \pm 0.4^{4}$ \\
21 & $7.3 \pm 1^{3}$ & $10.8 \pm 1.0^{4,5,6}$ \\
\hline
\end{tabular}

'Cells were grown on EHS matrix in the presence of lactogenic hormones for 0, 7, 14 or 21 days, collected and the triacylglycerol content measured by gas chromatography. Data are expressed as mean \pm SEM, $n=4$ /point. Statistical differences were determined by 1-way analysis of variance and Scheffés critical difference test.

${ }^{2} P<0.05$ v. day 0 and 7 .

${ }^{3} P<0.01$ v. day 0 and 7 and $P<0.05$ v. day 14

${ }^{4} P<0.01$ v. day 0 and 7 .

${ }^{5} P<0.01 \mathrm{v}$. day 14 or 2-way analysis of variance and Tukey's critical difference test. ${ }^{6} P<0.05$ v. day 21 with EFA.

Tukey's critical difference test (JMP Version 2, SAS, 1989) (Bruning and Kintz, 1987).

\section{RESULTS}

\section{Growth of mammary epithelial cells in culture}

Under the culture conditions used, the cells developed morphological characteristics reminiscent of dif-
TABLE 2. Percentage of fatty acid species in triacylglycerol from rat milk and rat mammary epithelial cells in culture for 14 days ${ }^{1}$

\begin{tabular}{lccc}
\hline \multirow{2}{*}{$\begin{array}{l}\text { Fatty } \\
\text { acid }\end{array}$} & \multicolumn{3}{c}{ Percent of total fatty acids } \\
\hline Milk & Cells + EFA & Cells \\
\hline $8: 0$ & $2.6 \pm 0.5$ & - & - \\
$10: 0$ & $9.0 \pm 0.6$ & $6.4 \pm 0.8$ & $11.9 \pm 0.9$ \\
$12: 0$ & $6.2 \pm 0.2$ & $7.9 \pm 1.0$ & $28.6 \pm 1.3$ \\
$14: 0$ & $3.8 \pm 1.3$ & $17.2 \pm 1.0$ & $23.0 \pm 0.8$ \\
$14: 1$ & - & $1.0 \pm 0.6$ & $2.8 \pm 0.7$ \\
$16: 0$ & $25.7 \pm 1.5$ & $24.5 \pm 1.8$ & $22.1 \pm 0.8$ \\
$16: 1$ & $1.0 \pm 0.1$ & $5.0 \pm 0.5$ & $6.1 \pm 0.2$ \\
$18: 0$ & $4.1 \pm 0.2$ & $1.7 \pm 0.5$ & $1.1 \pm 0.2$ \\
$18: 1$ & $28.0 \pm 3.3$ & $13.6 \pm 3.2$ & $4.5 \pm 0.4$ \\
$18: 2$ & $17.5 \pm 1.0$ & $11.2 \pm 1.1$ & - \\
$18: 3$ & $0.8 \pm 0.2$ & - & - \\
$20: 1$ & $0.3 \pm 0.1$ & - & - \\
$20: 2$ & $0.2 \pm 0.01$ & - & - \\
$20: 4$ & $0.7 \pm 0.04$ & $1.1 \pm 0.3$ & - \\
$22: 0$ & $0.3 \pm 0.04$ & $0.5 \pm 0.4$ & - \\
\hline
\end{tabular}

${ }^{1}$ Cells were grown on EHS matrix in the presence of lactogenic hormones with or without essential fatty acids (EFA) for 14 days. They were collected and the fatty acids species in triacylglycerol were measured by gas chromatography. Milk was collected from 15 day lactating rats and the fatty acids were measured by the same procedure. Data are expressed as mean \pm SEM, $n=4$ /point.

ferentiated mammary epithelial cells in the lactating mammary gland. Over the course of 21 days they formed multicellular structures with long branching projections radiating from a central alveolus and were filled with numerous lipid droplets (Fig. 1A and 1B). The alveolar structures had a hollow central lumen and numerous apical microvilli (an indication of cell polarity which is an important characteristic of secretory cells). The cells contained lipid droplets, casein secretory vesicles, and distinct mitochondria (Fig. 2). Distinct tight junctions were observed between the cells which formed the duct lumen (Fig. 5). Cultured cells were confirmed to be mammary epithelial cells by staining with FITC-conjugated anti-epithelial membrane antigen which reacts strongly with normal mammary epithelium and breast carcinoma metastases. Clusters of cells organized in an alveolar structure stained strongly with the antibody, while CWSV1 (SV40 transformed) hepatocytes did not (data not shown).

\section{Lipid synthesis in cell culture}

The synthesis of large amounts of lipid was confirmed by oil red $\mathrm{O}$ staining (Fig. 1B). We observed significant accumulation of intracellular triacylglycerol during the 21 days in culture (Table 1). Medium chain fatty acids constituted almost $19 \%$, and short chain fatty acids almost $3 \%$, of the total fatty acids in rat milk triglyceride (Table 2). These characteristic milk fatty acids also were made by cultured mammary epithelial cells (Table 2). Cultured mammary epithelial cells synthesized triglyceride without any added source of free fatty acids (Table 1 ). D- $\left[2-{ }^{14} \mathrm{C}\right]$ glucose, $\left[1-{ }^{14} \mathrm{C}\right]$ oleic acid and $\left[\mathrm{U}_{-}{ }^{14} \mathrm{C}\right]$ glycerol could all be used as precursors for triacylglycerol synthesis (Fig. 3).

\section{Lipid secretion in cell culture}

The cultured mammary epithelial cells secreted lipid into the ducts from their apical surfaces (Figs. 4 and 5). The secreted lipid droplets (Fig. 5) had a bilayer membrane surrounding the triacylglycerol core. The basal 


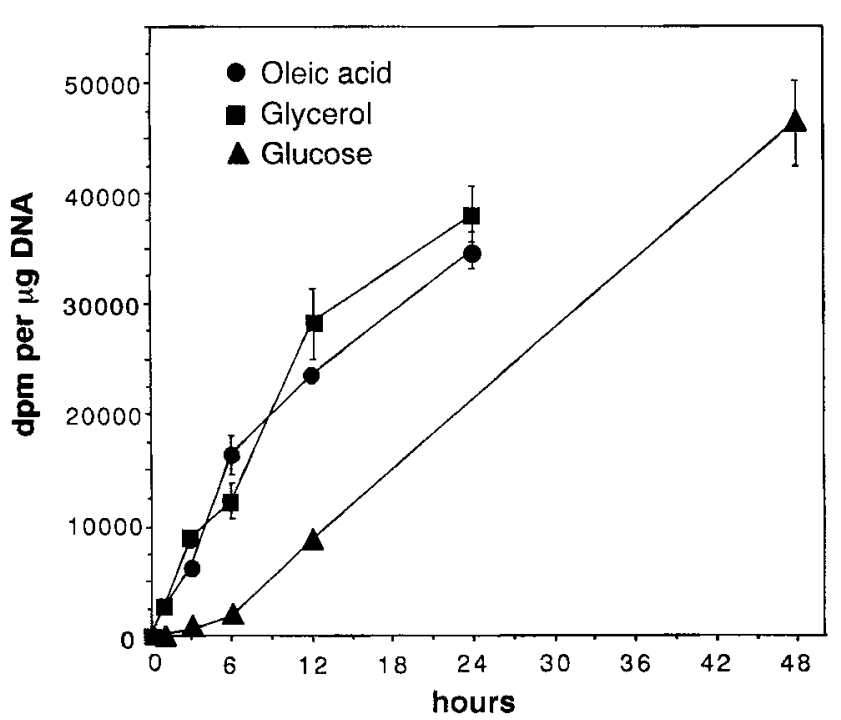

Fig. 3. Incorporation of radiolabeled precursors into triacylglycerol. Mammary epithelial cells were grown on EHS matrix in the presence of lactogenic hormones for 14 days then incubated with $\mathrm{D}-\left[2{ }^{14} \mathrm{C}\right] \mathrm{glu}$ cose, $\left[1-{ }^{14} \mathrm{C}\right]$ oleic acid or $\left[\mathrm{U}-{ }^{14} \mathrm{C}\right]$ glycerol for the indicated times. The cells were collected and the triacylglycerol separated on silica-gel TLC plates as described in materials and methods. Radioactivity was quantified using an imaging radiometric scanner. Data are expressed as mean $\pm S E M, n=4$ point.

level of lipid secretion was relatively low compared to the quantity of lipid synthesized. When the cells were labeled with $\left[1-{ }^{14} \mathrm{C}\right]$ oleic acid $1.3 \pm 0.3 \%$ of the labeled triacylglycerol was secreted in $24 \mathrm{hr}$. Phosphatidylcholine also was labeled and secreted $(99 \pm 12 \mathrm{dpm} / \mu \mathrm{g}$ DNA per $24 \mathrm{hr}$ ).

\section{Stimulation of lipid secretion}

Many potential secretagogues were tested for their ability to increase the basal level of lipid secretion (Table 3 ). Fetal bovine serum increased secretion 3 -fold ( $P$ $<0.01$ ). This experiment was repeated with a similar results $(323 \pm 55 \%$ of control; $P<0.01)$. None of the other potential secretagogues, listed in Table 3 , consistently stimulated a significant increase in secretion when added to the medium individually.

The combination of phorbol 12-myristate 13-acetate (PMA) and staurosporine (SS) increased secretion tenfold above control ( $P<0.01$; Fig. 8). PMA or SS, when added individually, did not consistently increase secretion significantly (Fig. 8). Several different doses and combinations of PMA and SS were tested. While both a higher concentration of SS (100 $\mathrm{nM})$ and a lower concentration of PMA $(0.025 \mu \mathrm{M})$ were effective in certain combinations, the original treatment (PMA $0.25 \mu \mathrm{M}$ and SS $20 \mathrm{nM}$ ) was the most effective $(P<0.01)$ (Fig. 8$)$ The effectiveness of PMA and SS together also declined with decreasing concentrations of SS, and became ineffective at $\leqslant 0.2 \mathrm{nM}$ (Fig. 8). The experiments described in Figure 8 were repeated six times. In all studies 0.25 $\mu \mathrm{M}$ PMA and $20 \mathrm{nM}$ SS stimulated a 5-10 fold increase in lipid secretion (in all studies $P<0.01$ ).

Some of the reported effects of PMA and SS occur within minutes after exposure. Therefore, we tested the

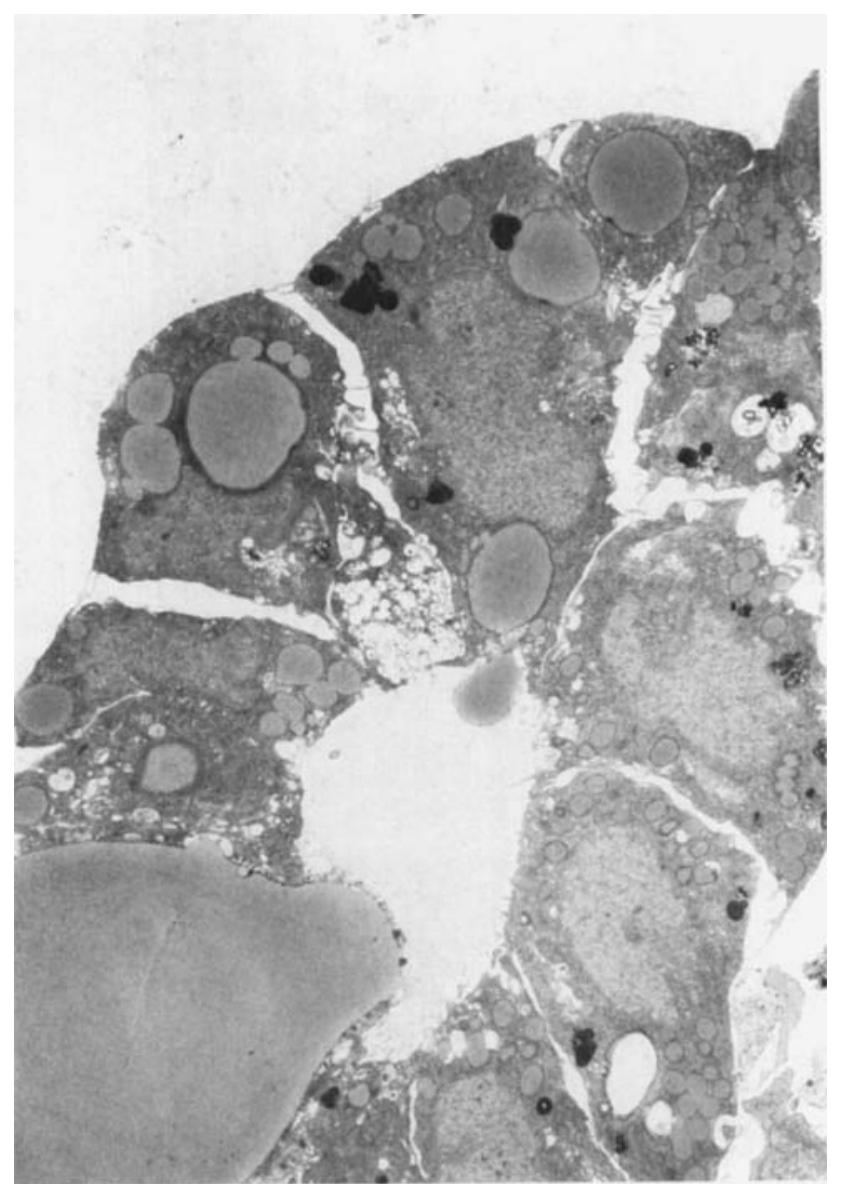

Fig. 4. Lipid secretion from mammary epithelial cells in culture. Mammary epithelial cells were grown for 14 days as described in Figure legend 1, and then fixed and processed according to the procedure described in materials and methods. Note large lipid droplet in the process of protruding through plasma membrane and smaller lipid droplet within lumen

effect of a 30 minute and 10 minute exposure of the cells to PMA and SS followed by a 72 hour incubation period with defined medium that did not contain these agents. The medium was collected at 24 and 72 hours and pooled for analysis of total secreted triacylglycerol. After exposure to PMA and SS for 30 minutes, triacylglycerol secretion increased 8 -fold $(P<0.01$; Table 4$)$. This experiment was repeated with similar results $(1,018 \pm$ $245 \%$ of control, $P<0.01$ ). After exposure to PMA and $\mathrm{SS}$ for $\mathbf{1 0} \mathrm{min}$, triacylglycerol secretion increased 3-fold $(P<0.01 ;$ Figure 7$)$.

Barcellos-Hoff and colleagues used EGTA to disrupt tight junctions between mammary epithelial cells in culture in order to study secretion of proteins (Barcellos-Hoff, et al., 1989). We determined whether similar treatment might enhance lipid secretion in our model sytem. EGTA made cell ducts permeable to trypan blue, while staurosporine and PMA did not (Fig. 6). EGTA did not result in increased lipid secretion (Fig. 7).

To determine if the PMA and SS treatment was releasing triacylglycerol by killing cells, cell viability after 72 hours of treatment with PMA and SS was evalu- 


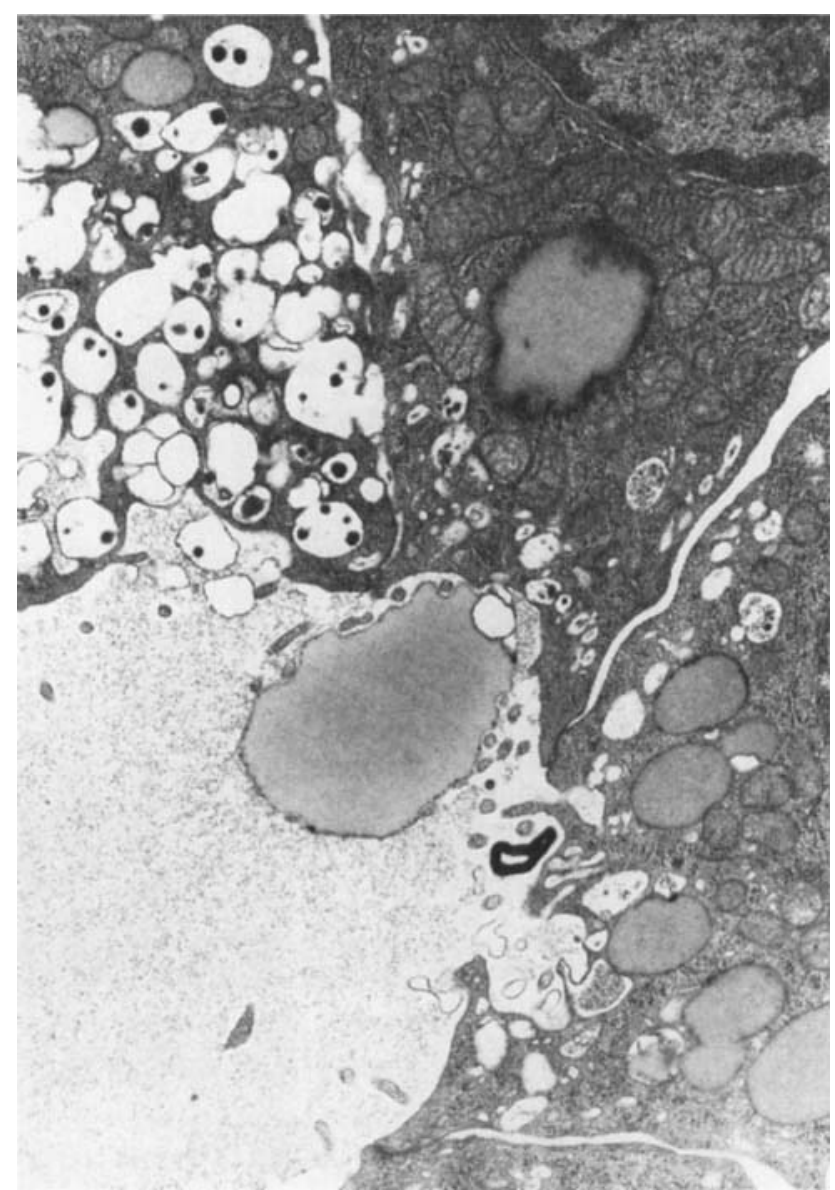

Fig. 5. Lipid secretion from mammary epithelial cells in culture. Enlarged view from Fig. 4 showing lipid droplet in duct. Note abundant endoplasmic reticulum, casein vesicles, tight junctions between cells and secreted lipid droplet with bilayer membrane.

ated by measurement of mitochondrial dehydrogenase activity (MTT assay) and electron microscopy. There was no significant difference between the control and treated groups by either method of assessment. Electron microscopic evaluation of cells after 72 hours exposure to PMA and SS showed normal looking, intact cells (data not shown) with distinct plasma and nuclear membranes, numerous mitochondria, and intact lipid droplets.

\section{Effect of other protein kinase inhibitors}

To determine if the inhibition of a particular protein kinase, in combination with PMA, was stimulating triacylglycerol secretion, the cells were incubated with protein kinase inhibitors thought to be more specific than staurosporine. KT5720, a cAMP-dependent protein kinase inhibitor (Kase, et al., 1987), alone or in combination with PMA, did not stimulate secretion (Table 5). KT5823, a cGMP-dependent protein kinase inhibitor (Ito and Karachot, 1990), did not stimulate triacylglycerol secretion when administered alone (Table 5), but did increase secretion 5 -fold $(P<0.01)$ in combination with PMA. Calphostin $\mathrm{C}$, a specific inhibitor of PKC, was tested but proved to be toxic to the cells,
TABLE 3. Potential secretagogues tested for stimulation of triacylglycerol secretion from rat mammary epithelial cells in vitro'

\begin{tabular}{|c|c|}
\hline & $\%$ control \\
\hline \multicolumn{2}{|l|}{ Hormones } \\
\hline Prolactin & $180 \pm 27$ \\
\hline Progesterone $1 \mu \mathrm{g} / \mathrm{ml}$ & $132 \pm 22$ \\
\hline Oxytocin $\quad 250 \mu \mathrm{U} / \mathrm{ml}$ & $162 \pm 64$ \\
\hline $1000 \mu \mathrm{U} / \mathrm{ml}$ & $155 \pm 62$ \\
\hline Thyroxine & $268 \pm 109$ \\
\hline $500 \mathrm{ng} / \mathrm{ml}$ & $234 \pm 26$ \\
\hline $17 \beta$-estradiol $0.1 \mathrm{ng} / \mathrm{ml}$ & $121 \pm 35$ \\
\hline $1.0 \mathrm{ng} / \mathrm{ml}$ & $196 \pm 48$ \\
\hline $10.0 \mathrm{ng} / \mathrm{ml}$ & $223 \pm 43$ \\
\hline \multicolumn{2}{|l|}{ PKA agonists } \\
\hline Cholera toxin $100 \mathrm{ng} / \mathrm{ml}$ & $59 \pm 10$ \\
\hline Dibutyryl cAMP $100 \mu \mathrm{M}$ & $109 \pm 8$ \\
\hline \multicolumn{2}{|l|}{ PKA inhibitors } \\
\hline KT5720 $100 \mathrm{nM}$ & $56 \pm 13$ \\
\hline \multicolumn{2}{|l|}{ PKC agonists } \\
\hline Phorbol 12 -myristate 13 -acetate $0.25 \mu \mathrm{M}$ & $118 \pm 18$ \\
\hline $0.025 \mu \mathrm{M}$ & $157 \pm 27$ \\
\hline \multicolumn{2}{|l|}{ PKC inhibitors } \\
\hline Staurosporine $20 \mathrm{nM}$ & $232 \pm 48$ \\
\hline $100 \mathrm{nM}$ & $128 \pm 41$ \\
\hline Sphingosine $25 \mu \mathrm{M}$ & $302 \pm 67$ \\
\hline Calphostin C $100 \mathrm{nM}$ & toxic \\
\hline \multicolumn{2}{|l|}{ cGMP dependent protein kinase inhibitor } \\
\hline $\mathrm{KT} 5823500 \mathrm{nM}$ & $122 \pm 20$ \\
\hline \multicolumn{2}{|l|}{ Phorbol which does not stimulate PKC } \\
\hline $4 \alpha$-Phorbol 12,13 didecanoate $0.25 \mu \mathrm{M}$ & $139 \pm 33$ \\
\hline \multicolumn{2}{|l|}{ Other } \\
\hline Fetal bovine serum $10 \%$ & $306 \pm 27^{* *}$ \\
\hline Bovine pituitary extract $50 \mu \mathrm{g} / \mathrm{ml}$ & $51 \pm 13$ \\
\hline Choline $28 \mathrm{mg} / \mathrm{L}$ & $140 \pm 54$ \\
\hline Carbachol $100 \mu \mathrm{M}$ & $97 \pm 22$ \\
\hline Linolenic acid $16.5 \mu \mathrm{M}+$ linoleic acid $7.14 \mu \mathrm{M}$ & $54 \pm 6^{*}$ \\
\hline
\end{tabular}

'Mammary epithelial cells were grown on EHS matrix in the presence of lactogenic hormones for 14 days then labeled with [methyl- ${ }^{14} \mathrm{C}$ ] oleic acid for 4 hours. The oleic acid was removed, the cells were washed twice and medium with potential secretagogues was added. The incubation was continued for 72 hours and the medium was collected at 24 and 72 hours. The samples of medium were pooled for analysis. The metabolites were separated on silica gel TLC plates using hexane:ethyl ether:acetic acid $(50: 50: 1, v / v)$ and the radioactivity was quantified using an imaging radiometric scanner. Data are expressed as mean + SEM, $n=4$ /point except for cholera toxin and bovine pituitary pressed as mitary extract treatments where $n=2$. Statistical differences were determined by one-way analysis of variance and Dunnett's critical difference test, ${ }^{* *}=P<0.01$ and unpaired
t-test, $* \cdots P<0.05$

TABLE 4. Triacylglycerol secretion from mammary epithelial cells when stimulated by phorbol 12-myristate 13-acetate (PMA) and staurosporine (SS) for 30 minutes $^{1}$

\begin{tabular}{lc}
\hline & \% control \\
\hline Control & $100 \pm 12$ \\
PMA 0.25 $\mu \mathrm{M}$ & $397 \pm 93$ \\
SS 20 nM & $290 \pm 40$ \\
PMA 0.25 $\mu \mathrm{M}+$ SS $20 \mathrm{nM}$ & $839 \pm 130^{*}$ \\
\hline
\end{tabular}

${ }^{1}$ Mammary epithelial cells were grown on EHS matrix in the presence of lactogenic hormones for 14 days then incubated with [methyl- ${ }^{14} \mathrm{C}$ ] oleic acid for 4 hours. The cells were stimulated with PMA SS or both as indicated above, for 30 minutes. The stimula were stimulated with a described in Figure 3. Data are expressed as mean \pm SEM, $n=4 /$ point. Statistical differences were determined by one-way analysis of variance and Dunnett's critical difference test, $*=P<0.01$. This experiment was repeated two times with similar results.

even in the 30 minute stimulation protocol. Sphingosine, an inhibitor of PKC (Hannun, et al., 1986) was used alone and in combination with PMA (Table 5). The latter treatment stimulated triacylglycerol secretion almost 14-fold $(P<0.01)$. In this experiment PMA alone also stimulated a significant increase in triacylglycerol secretion (to $526 \pm 109 \%$ of control; $P<0.01$ ). PMA, alone, often increased secretion above control 

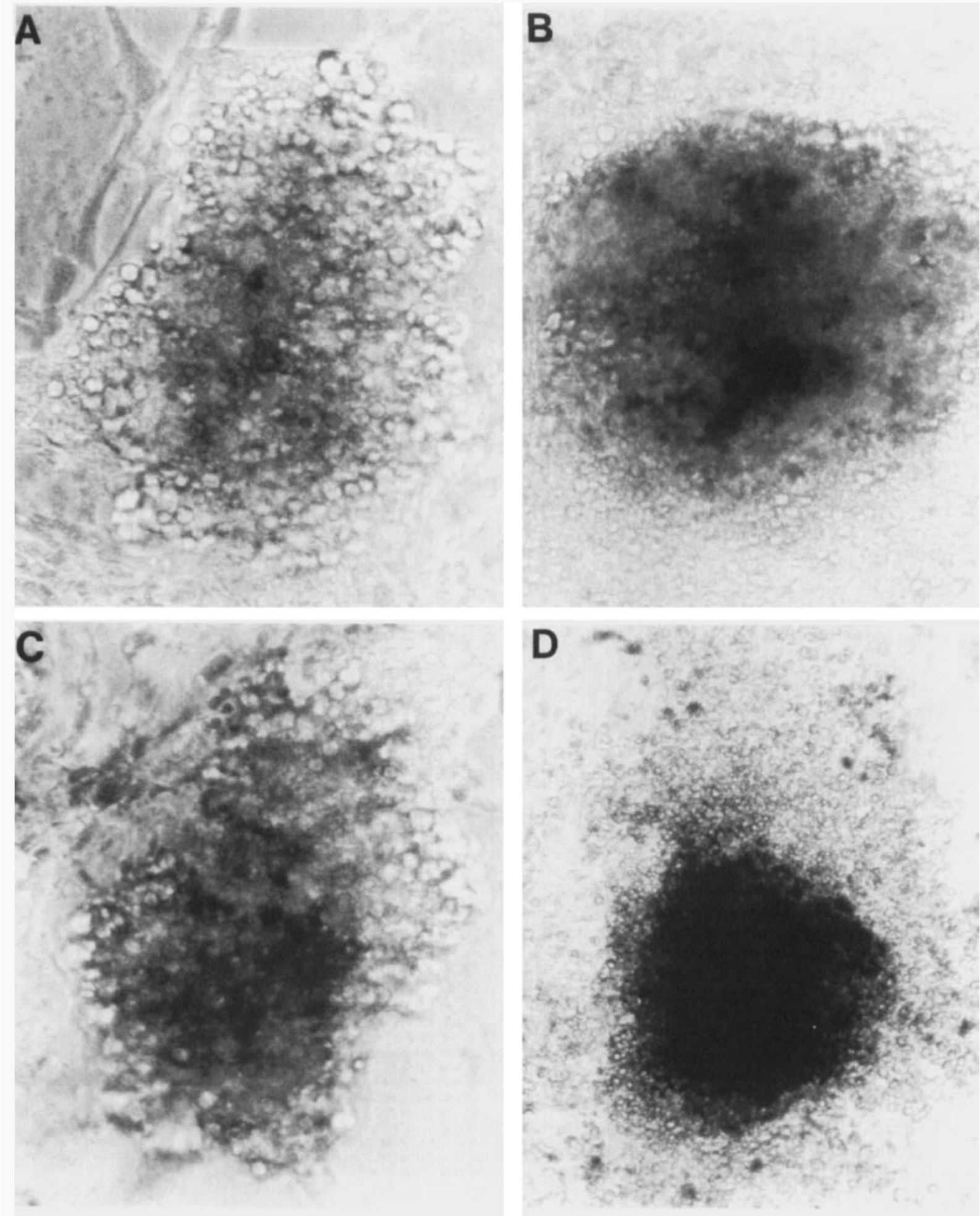

Fig. 6. Disruption of cell-cell junctions by EGTA treatment. Mammary epithelial cells were grown for 14 days as described in Figure legend 1 and then treated in the following manner: panel $\mathbf{A}$ ) untreated; B) incubated for 15 minutes at room temperature in media containing $1 \%$ trypan blue; $\mathrm{C})$ incubated with PMA $(0.25 \mu \mathrm{M})$ and SS $(20 \mathrm{nM})$ for 10 minutes at $37^{\circ} \mathrm{C}$ followed by the same concentration of

PMA and SS in the presence of $1 \%$ trypan blue for 10 minutes at room temperature; D) incubated with EGTA $(2.5 \mathrm{mM}$ in calcium free DMEM) for 10 minutes at $37^{\circ} \mathrm{C}$ followed by $1.2 \mathrm{mM}$ EGTA in the presence of $1 \%$ trypan blue for 10 minutes at room temperature. Following the exposure to trypan blue the wells were washed with PBS and the cells photographed. 


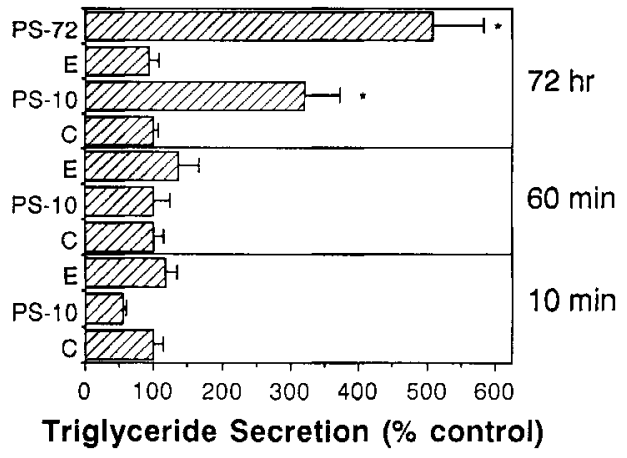

Fig. 7. Triacylglycerol secretion from mammary epithelial cells: Effects of EGTA and phorbol 12-myristate 13-acetate (PMA) and staurosporine (SS). Mammary epithelial cells were grown for 14 days as described in Figure legend 1 and then treated with nothing (C); 2.5 mM EGTA for 10 minutes in calcium free DMEM (E); PMA $(0.25 \mu \mathrm{M})$ and SS (20 nM) for 10 minutes (PS-10); or PMA $(0.25 \mu \mathrm{M})$ and SS (20 $\mathrm{nM}$ ) for 72 hours (PS-72). Release of triacylglycerol was measured as described in Methods. Data are shown for medium collected at 10 minutes, 60 minutes and 72 hours after treatment. Data are expressed as mean percent control \pm SEM, $n=5$ /point. Statistical differences were determined by one-way analysis of variance and Dunnett's critical difference test. $*=P<0.01$.

values, however in most experiments, the effect was not statistically different from control.

\section{Effect of $4 \alpha$-phorbol 12,13 didecanoate}

To determine if PMA was acting through PKC activation or through one of the many other known actions of phorbol esters, the cells were incubated with a phorbol ester that does not activate PKC, $4 \alpha$-phorbol 12,13 didecanoate (Castagna, et al., 1982). The combination of $4 \alpha$-phorbol 12,13 didecanoate (obtained from Sigma) and SS increased secretion 6 -fold $(P<0.01$; Table 6 ). Using 4 $\alpha$-phorbol 12,13 didecanoate obtained from another source (Calbiochem), we again observed that, in combination with SS, it stimulated secretion of triacylglycerol (to $693 \pm 226 \%$ of control, $P<0.05$, data not shown). It is unlikely that both preparations of $4 \alpha$-phorbol 12,13 didecanoate could have been contaminated with the $\beta$-isomer (a PKC agonist).

\section{DISCUSSION}

We have shown that rat mammary epithelial cells grown on a thin layer of EHS matrix synthesize and secrete triacylglycerol. Mammary epithelial cells have been cultured on a variety of substrates including collagen (Emerman and Pitelka, 1977; Richards et al., 1983), floating collagen gels (Hamamoto, et al., 1988; Imagawa, et al., 1982; Lee, et al., 1985; Rocha et al., 1987) and mammary derived matrix (Wicha, et al., 1982). While these systems often expressed differentiated structure and function (i.e. casein synthesis), there was little evidence that they supported lipid synthesis or secretion. Emerman and Pitelka (1977) reported that accumulation of lipid in mid-pregnant mouse mammary epithelial cells cultured on floating collagen gels. However, these cells underwent limited proliferation and there was no indication of lipid secretion. Recently, a culture system was developed where mammary epithelial cells isolated from virgin rats were grown in a suspension of EHS matrix (Hahm and Ip, 1990, Hahm, et al., 1990). These cells formed budding colonies with duct-like projections, synthesized casein and accumulated lipid as verified by oil red $\mathrm{O}$ staining (Hahm and Ip, 1990, Hahm, et al., 1990). The observation of lipid droplets within the lumen of the ducts suggested that these cells might secrete lipid, however no attempt was made to quantify this aspect of mammary cell function (Darcy, et al., 1991; Hahm and Ip, 1990; Hahm, et al., 1990). A disadvantage of this system was that the cells were embedded in EHS matrix, making measurementof secretion nearly impossible. Intra- and extracellular lipid droplets also have been observed in alveoli cultured from mid-pregnant mouse mammary epithelial cells grown on a layer of EHS matrix (Aggeler, et al., 1991; Barcellos-Hoff, et al., 1989).

Like mammary epithelial cells of the lactating gland, our cultured cells synthesized large amounts of triacylglycerol. After 21 days in culture they contained 38 times more triacylglycerol than did the freshly isolated cells. They used glucose, oleate, and glycerol as precursors for triacylglycerol synthesis (Fig. 3), and they made short and medium chain fatty acids. The mammary is the only known tissue which contains thioesterase II, the enzyme responsible for termination of acyl chain elongation prior to 16 carbon atoms (Smith, 1980). In our cell culture system, secreted fat droplets had a bilayer membrane characteristic of lipid droplets secreted by the mammary gland in vivo. Thus, cells in culture secreted lipid in a form similar to, if not identical to, that which occurs in vivo.

We observed that 1 to $2 \%$ of the labeled intracellular triacylglycerol was secreted in 24 hours by unstimulated cells. Disrupting cell-cell tight junctions with EGTA did not release additional triglyceride, though it did make ducts permeable to trypan blue (Fig. 7). This suggests that triacylglycerol did not accumulate in large amounts within ducts. Phosphatidylcholine was also secreted into the medium.

The low basal level of secretion may indicate that the cells, in order to secrete normally, required some signal or supplement which they were not receiving in the defined medium. The addition of FBS increased secretion 3-fold. Serum contains many growth factors and hormones which can stimulate gene transcription. Several hormones involved in lactogenesis, and other chemicals which are known to exert specific cellular effects, were tested for their ability to increase secretion of labeled triacylglycerol. None of the other supplements, when added alone, consistently increased secretion. However, when PMA was combined with certain protein kinase inhibitors, lipid secretion increased markedly. The effect was very reproducible, stimulating secretion between $500-1,000 \%$ of control. Cell viability, as assessed by MTT assay and electron microscopy was not affected by these treatments. In most studies PMA, alone, stimulated an increase in lipid secretion. However, this effect was variable. If, as we suggest, two signals were needed to enhance secretion, it is possible that physiologic variation in protein $\mathrm{ki}$ nase activity within cells sometimes primed cells to respond to PMA, resulting in stimulated lipid secretion. One hypothesis that might explain our observation is that PMA and SS disrupted cell-cell contact, 


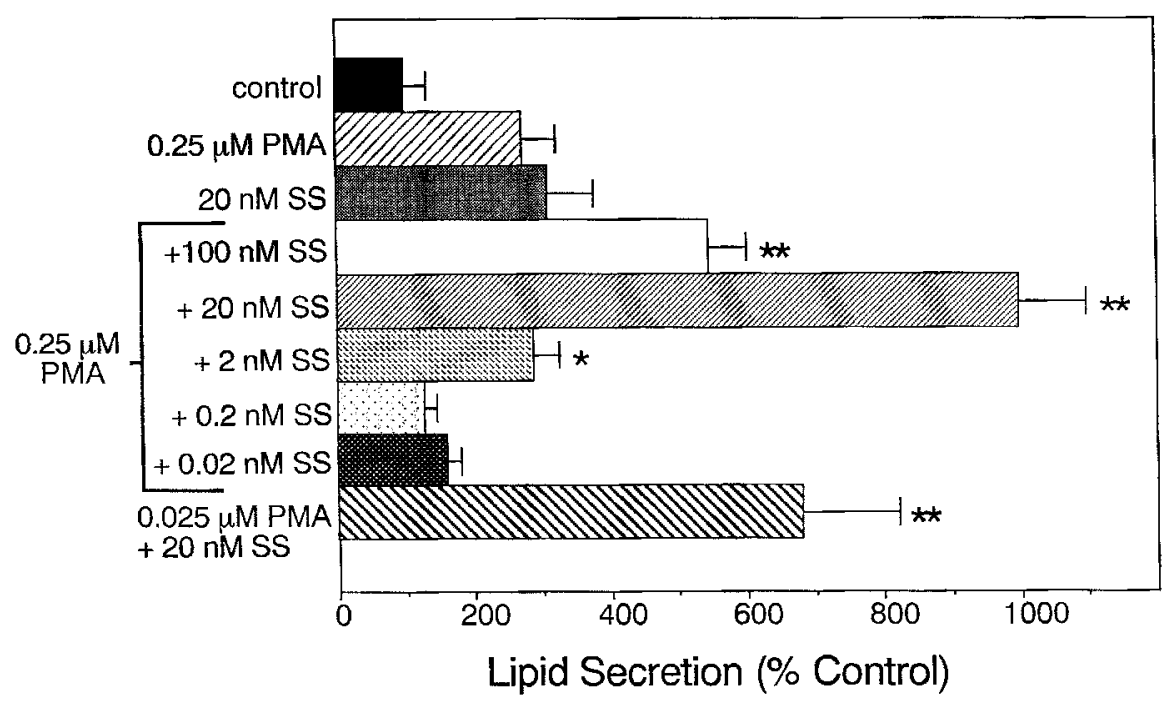

Fig. 8. Triacylglycerol secretion from mammary epithelial cells: Effects of phorbol 12-myristate 13-acetate (PMA) and staurosporine (SS). Mammary epithelial cells were grown on EHS matrix in the presence of lactogenic hormones for 14 days. PMA andor SS were added at the concentrations indicated, and release of triacylglycerol was measured as described in Methods. Data are shown from three

TABLE 5. Triacylglycerol secretion from mammary epithelial cells when stimulated by phorbol 12-myristate 13-acetate (PMA) and protein kinase inhibitors

\begin{tabular}{|c|c|}
\hline & $\%$ control \\
\hline Control & $100 \pm 60$ \\
\hline KT5720 $100 \mathrm{nM}$ & $56 \pm 13$ \\
\hline PMA $0.25 \mu \mathrm{M}+\mathrm{KT} 5720100 \mathrm{nM}$ & $86 \pm 13$ \\
\hline Control & $100 \pm 25$ \\
\hline PMA $0.25 \mu \mathrm{M}$ & $321 \pm 24$ \\
\hline KT5823 $500 \mathrm{nM}$ & $122 \pm 20$ \\
\hline PMA $0.25 \mu \mathrm{M}+\mathrm{KT} 5823500 \mathrm{nM}$ & $515 \pm 74^{*}$ \\
\hline Control & $100 \pm 60$ \\
\hline PMA $0.25 \mu \mathrm{M}$ & $526 \pm 109^{*}$ \\
\hline Sphingosine $25 \mu \mathrm{M}$ & $302 \pm 67$ \\
\hline PMA $0.25 \mu \mathrm{M}+$ Sphingosine $25 \mu \mathrm{M}$ & $1361 \pm 410^{*}$ \\
\hline
\end{tabular}

thereby releasing a pool of lipid trapped within ducts. As discussed earlier, EGTA made ducts permeable to trypan blue but did not enhance lipid secretion. Treatment with PMA and SS enhanced lipid secretion without making ducts permeable to trypan blue (Fig. 7). Perhaps, only a subset of our alveolar-like structures has ducts which were sealed off from the medium. In addition, secretion of lipid occurred hours after exposure to PMA and SS and continued for a 72 hour period.

The optimal dose of staurosporine was $20 \mathrm{nM}$, with decreasing activity at $100 \mathrm{nM}$ and loss of activity between $2.0 \mathrm{nM}$ and $0.2 \mathrm{nM}$. Staurosporine is capable of inhibiting, with varying degrees of potency, several different protein kinases including: PKC, PKA, $\mathrm{Ca}^{2+}$ Calmodulin-dependent protein kinase II, myosin light chain kinase, $\mathrm{p} 60^{\mathrm{vsre}}$ protein tyrosine kinase, protein pooled experiments in which control secretion was $100 \%( \pm 14), 100 \%$ $( \pm 60)$ and $100 \%( \pm 33)$. Data are expressed as mean percent control \pm SEM, $\mathrm{n}=5$ /point. Statistical differences were determined by one-way analysis of variance and Dunnett's critical difference test $*=P<0.05$; *** $=P<0.01$

TABLE 6. Triacylglycerol secretion from mammary epithelial cells when stimulated by $4 \alpha$-phorbol 12,13 didecanoate ( $4 \alpha-P D D)$ and staurosporine (SS) ${ }^{i}$

\begin{tabular}{|c|c|}
\hline & $\%$ control \\
\hline Control & $100 \pm 60$ \\
\hline $4 \alpha-P D D 0.25 \mu \mathrm{M}$ & $139 \pm 33$ \\
\hline $4 \alpha-P P D 0.25 \mu \mathrm{M}+\mathrm{SS} 20 \mathrm{nM}$ & $603 \pm 130^{*}$ \\
\hline
\end{tabular}

${ }^{1}$ Mammary epithelial cells were grown on EHS matrix in the presence of lactogenic hormones for 14 days and treated according to the procedure described in Table 3. Data are expressed as mean + SEM, $n=4$ /point. Statistical differences were determined by one-way analysis of variance and Dunnett's critical difference test, ${ }^{*}-P<0.01$.

tyrosine kinase of EGF receptor, and cGMP dependent protein kinase (Nakanishi, et al., 1991; Nanko, et al., 1987; Tamaoki, et al., 1986; Yanagihara, et al., 1991). The diminishing effect of staurosporine at lower concentrations may be related to loss of inhibition of one or more of these protein kinases.

The effect of the combination of PMA and SS on cell secretory processes is not unique to mammary epithelial cells. Secretion of urokinase-type plasminogen activator from porcine epithelial cells is induced by SS and potentiated by the addition of PMA and calcitonin (Dierks-Ventling, et al., 1989).

In our secretion studies, SS could be replaced, to some extent, by KT5823, a cGMP-dependent protein kinase inhibitor derived from a microbial source (Ito and Karachot, 1990), and by sphingosine, a PKC inhibitor (Hannun, et al., 1986; Table 5). Sphingosine also inhibits insulin receptor tyrosine kinase (Arnold and Newton, 1991), $\mathrm{Ca}^{2+} /$ Calmodulin dependent protein kinase and smooth muscle myosin light chain kinase (Jefferson and Schulman, 1988). In addition, sphingosine has been shown to activate casein kinase II (McDonald, et al., 1991). Thus, we conclude that lipid secretion re- 
quires the inhibition of a protein kinase, but are unable to identify the specific kinase involved.

PMA has various cellular effects, most notably the stimulation of PKC (Castagna, et al., 1982) and promotion of epidermal carcinogenesis (Diamond, 1984). Our observation, that PMA could be replaced by $4 \alpha$-phorbol 12,13 didecanoate, a phorbol ester which does not stimulate PKC (Castagna, et al., 1982), suggests that the effect of phorbol esters on lipid secretion was not mediated by PKC activation. The mechanism of action of $4 \alpha$-phorbol 12,13 didecanoate is not known. PMA, via mechanisms independent of PKC activation, regulates the expression of genes including viral and cellular genes and cellular homologues of viral oncogenes (Rahmsdorf and Herrlich, 1990). It is suspected, but not proven, that $4 \alpha$-phorbol 12, 13 didecanoate has similar, PKC-independent, effects on gene transcription. Some of these effects of phorbol esters are mediated through binding of regulatory proteins (i.e. AP-1) to responsive elements in the control regions of certain genes (Rahmsdorf and Herrlich, 1990).

The effects of PMA and staurosporine as mammary lipid secretagogues were apparent even after a brief 10 minutes (Fig. 7) or 30 minutes (Table 4) treatment. Since PMA stimulates PKC though high affinity binding to its regulatory domain, its effects might continue for the duration of the 72 hour incubation. Staurosporine binds reversibly to $\mathrm{PKC}\left(\mathrm{t}_{1 / 2}\right.$ of 69 minutes; Gross, et al., 1990). Therefore, the inhibition of PKC by staurosporine should not have continued long after it was removed. The inhibition of other protein kinases by staurosporine has not been characterized and could be irreversible. These results support our earlier conclusion that cell death was not the mechanism whereby SS and PMA stimulated release of lipids; the 10 or 30 minute exposure periods would not have killed cells. We suggest that the signals responsible for secretion occur rapidly and their effects on secretion continue for at least 72 hours.

Apparently, two signals were needed to stimulate mammary lipid secretion. One involved the inhibition of a protein kinase, possibly either c-GMP dependent protein kinase or PKC. The other involved an effect of phorbol ester which is not mediated by PKD, possibly a gene transcription effect (perhaps permitting terminal differentiation of the mammary cells).

\section{ACKNOWLEDGMENTS}

This study was supported by grant HD26553 awarded by the National Institutes of Health, and by an Oncobiology training grant T32 CA9423 to ER. We thank the UNC Lineberger Comprehensive Cancer Center for use of core tissue culture support facilities. Some of the work presented in this manuscript formed part of ER's dissertation for the Ph.D. degree. A portion of this data was presented previously in abstract form in FASEB J. (1992) 6:A1116.

\section{LITERATURE CITED}

Aggeler, J., Ward, J., Blackie, L.M., Barcellos-Hoff, M.H., Streuli, C.H., and Bissell, M.J. (1991) Cytodifferentiation of mouse mammary epithelial cells cultured on a reconstituted basement membrane reveals striking similarities to development in vivo. J. Cell Sci., 99:407-417.
Arnold, R.S., and Newton, A.C. (1991) Inhibition of the insulin receptor tyrosine kinase by sphingosine. Biochemistry, 30:7747-7754.

Barcellos-Hoff, M.H., Aggeler, J., Ram, T.G., and Bissell, M.J. (1989) Functional differentiation and alveolar morphogenesis of primary mammary cultures on reconstituted basement membrane. Development, 105:223-235.

Bartholomeusz, R.K., Bruce, N.W., Martin, C.E., and Hartmann, P.E. (1976) Serial measurement of arterial plasma progesterone levels throughout gestation and parturition in individual rats. Acta Endocrinol. (Copenh), 82:436-443.

Bligh, E.G., and Dyer, W.J. (1959) A rapid method of total lipid extraction and purification. Can. J. Biochem. Physiol., 37:911-917.

Bruning, J.L., and Kintz, B.L. (1987) Computational Handbook of Statistics. Scott, Foresman, Glenview, II , pp. 372.

Bucheim, W., Weslch, U., and Patton, S. (1988) Electron microscopy and carbohydrate histochemistry of the human milk fat globule membrane. In: Biology of Human Milk. L.A. Hanson, ed. Raven Press, New York, Vol. 15, pp. 27-44.

Cameron, C.M., and Rillema, J.A. (1983) Extracellular calcium ion concentration required for prolactin to express its actions on casein, ribonucleic acid and lipid biosynthesis in mouse mammary gland explants. Endocrinology, 113:1596-1600.

Cameron, C.M., Linebaugh, B.E., and Rillema, J.A. (1983) Hormonal control of lipid metabolism in mouse mammary gland explants. Endocrinology, 112:1007-1011.

Carmichael, J., DeGraff, W.G., Gazdar, A.F., Minna, J.D., and Mitchell, J.B. (1987) Evaluation of a tetrazolium-based semiautomated colorimetric assay: assessment of chemosensitivity testing. Cancer Res., 47:936-942.

Castagna, M., Takai, Y., Kaibuchi, K., Sano, K., Kikkawa, U., and Nishizuka, Y. (1982) Direct activation of calcium-activated, phospholipid-dependent protein kinase by tumor-promoting phorbol esters. J. Biol. Chem., 257:7847-7851.

Chatterton, R.T., Harris, J.A., and Wynn, R.M. (1975) Lactogenesis in the rat: an ultrastructural study of the initiation of the secretory process. J. Reprod. Fertil., 43:479-484.

Collier, R.J., Bauman, D.E., and Hays, R.L. (1977) Lactogenesis in explant cultures of mammary tissue from pregnant cows. Endocrinology, 100:1192-1200.

Cordell, J., Richardson, T.C., Pulford, K.A.F., Ghosh, A.K., Catter, K.C., Heyderman, E, and Mason, D.Y. (1985) Production of mono. clonal antibodies against human epithelial membrane antigen for use in diagonstic immunocytochemistry. Br. J. Cancer, 52:347-354.

Darcy, K.M., Black, J.D., Hahm, H.A., and Ip, M.M. (1991) Mammary organoids from immature virgin rats undergo ductal and alveolar morphogenesis when grown within a reconstituted basement membrane. Exp. Cell Res., 196:49-65.

Diamond, L. (1984) Tumor promoters and cell transformation. Pharmacol. Ther., 26:89-145.

Dierks-Ventling, C., Knesel, J., Nagamine, Y., Hemmings, B.A., Pehling, G., Fischer, F., and Fabbro, D. (1989) Staurosporine stimulates expression of the urokinase-type(u-PA) plasminogen activator in LLC-PK1 cells. Int. J. Cancer, 44:865 -870 .

Emerman, J.T., and Pitelka, D.R. (1977) Maintenance and induction of morphological differentiation in dissociated mammary epithelium on floating collagen membranes. In Vitro Cell. Dev. Biol., 13:316-328.

Freudenstein, C., Keenan, T.W., Eigel, W.N., Sasaki, M., Stadler, J., and Franke, W.W. (1979) Preparation and characterization of the inner coat material associated with fat globule membranes from bovine and human milk. Exp. Cell Res., 118:277-294

Gross, J.L., Herblin, W.F., Do, U.H., Pounds, J.S., Buenaga, L.J., and Stephens, L.E. (1990) Characterization of specific [3H]dimethylstaurosporine binding to protein kinase C. Biochem. Pharmacol., $40 \cdot 343-350$.

Hahm, H.A., and Ip, M.M. (1990) Primary culture of normal rat mammary epithelial cells within a basement membrane matrix. I. Regulation of proliferation by hormones and growth factors. In Vitro Cell. Dev, Biol., 26:791-802.

Hahm, H.A., Ip, M.M., Darcy, K., Black, J.D., Shea, W.K., Forczek, S., Yoshimura, M., and Oka, T. (1990) Primary culture of normal rat mammary epithelial cells within a basement membrane matrix. II. Functional differentiation under serum-free conditions. In Vitro Cell. Dev. Biol., 26:803-814.

Hamamoto, S., Imagawa, W, Yang, J., and Nandi, S. (1988) Morphogenesis of mouse mammary epithelial cells growing within collagen gels: ultrastructural and immunocytochemical characterization. Cell Growth Differ., 22:191-202.

Hannun, Y.A., Loomis, C.R., Merrill, A.H.J., and Bell, R.M. (1986) 
Sphingosine inhibition of protein kinase $\mathrm{C}$ activity and of phorbol dibutyrate binding in vitro and in human platelets. J. Biol. Chem., 261:12604-9.

Heyderman, E., Strudley, I., Powell, G., Richardson, T.C., Cordell, J.L and Mason, D.Y. (1985) A new monoclonal antibody to epithelial membrane antigen (EMA)-E29. A comparison of its immunocytochemical reactivity with polyclonal anti-EMA antibodies and with another monoclonal antibody, HMFG-2. Br. J. Cancer, 52:355-361.

Imagawa, W., Tomooka, Y., and Nandi, S. (1982) Serum-free growth of normal and tumor mouse mammary epithelial cells in primary culture. Proc. Natl. Acad. Sci. USA, 79:4074-4077.

Ito, M., and Karachot, L. (1990) Messengers mediating long-term desensitization in cerebellar Purkinje cells. Neuroreport, 1:129-132.

Jarasch, E., Bruder, G., Keenan, T.W., and Franke, W.W. (1977) Redox constituents in milk fat globule membranes and rough endoplasmic reticulum from lactating mammary gland. J. Cell Biol., 73:223-241.

Jefferson, A.B., and Schulman, H. (1988) Sphingosine inhibits calmodulin-dependent enzymes. J. Biol. Chem., 263:15241-15244.

Kase, H., Iwahashi, K., Nakanishi, S., Matsuda, Y., Yamada, K., Takahashi, M., Murakata, C., Sato, A., and Kaneko, M. (1987) K-252 compounds, novel and potent inhibitors of protein kinase $\mathrm{C}$ and cyclic nucleotide-dependent protein kinases. Biochem. Biophys. Res. Comm., 142:436-440.

Kishimoto, Y., and Hoshi, M. (1972) Isolation, purification and assay of fatty acids and steroids from the nervous system. In: Methods of Neurochemistry. R. Fried, ed. Mercel and Dekker, New York, Vol. 3, pp. $75-154$.

Kleinman, H.K., McGarvey, M.L., Hassell, J.R., Star, V.L., Cannon, F.B., Laurie, G.W., and Martin, G.R. (1986) Basement membrane complexes with biological activity. Biochemistry, 25:312-8.

Labarca, C., and Paigen, K. (1980) A simple, rapid and sensitive DNA assay procedure. Anal. Biochem., 102:344-352.

Lee, E.Y.P., Lee, W., Kaetzel, C.S., Parry, G., and Bissell, M.J. (1985) Interaction of mouse mammary epithelial cells with collagen substrata: Regulation of casein gene expression and secretion. Proc Natl. Acad. Sci. USA, 82:1419-1423.

Lewis, B.A., and Smith, F. (1969) Sugars and derivatives. In: ThinLayer Chromatography. E. Stahl, ed. Springer-Verlag, New York, pp. 807-837.

McDonald, O.B., Hannun, Y.A., Reynolds, C.H., and Sahyoun, N.
(1991) Activation of casein kinase II by sphingosine. J. Biol. Chem., 266:21773-21776

Nakanishi, S., Kase, H., and Matsuda, Y. (1991) Assay of myosin light chain kinase activity by high-performance liquid chromatography using a synthetic peptide as substrate. Anal. Biochem., 195:313-318.

Nanko, H., Kobayashi, E., Takahashi, I., Tamaoki, T., Kuzuu, Y., and Iba, H. (1987) Staurosporine inhibits tyrosine-specific protein kinase activity of rous sarcoma virus transforming protein $\mathrm{p} 60 . \mathrm{J}$. Antibiot. (Tokyo), $X L: 706-708$.

Rahmsdorf, H.J., and Herrlich, P. (1990) Regulation of gene expression by tumor promters. Pharmacol. Ther., 48:157-188.

Richards, J., Pasco, D., Yang, J., Guzman, R., and Nandi, S. (1983) Comparison of the growth of normal and neoplastic mouse mammary cells on plastic, on collagen gels and in collagen gels. Exp. Cell Res., 146:1-14.

Rocha, V., Hwang, S., and Ortiz, C.L. (1987) Casein secretion by marmmary gland epithelial from collagen gel cultures and lactating glands. J. Cell. Physiol., 132:343-348.

Sanford, K.K., Earle, W.R., Evans, V.J., Waltz, H.K., and Shannon, J.E. (1950) The measurement of proliferation in tissue cultures by enumeration of cell nuclei. J. Natl. Cancer Inst. 11:773-795.

Smith, S. (1980) Mechanism of chain length determination in biosynthesis of milk fatty acids. J. Dairy Sci., 63:337-352.

Tacconi, M., and Wurtman, R.J. (1985) Rat brain phosphatidyl-N,Ndimethylethanolamine is rich in polyunsaturated fatty acids. $\mathrm{J}$ Neurochem., 45:805-809.

Tamaoki, T., Nomoto, H., Takashashi, I., Kato, Y., Morimoto, M., and Tomita, F. (1986) Staurosporine, a potent inhibitor of phospholipid/ $\mathrm{Ca}++$ dependent protein kinase. Biochem. Biophys. Res. Comm., 135:397-402.

Wicha, M.S., Lowrie, G., Kohn, E., Bagavandos, P., and Mahn, T. (1982) Extracellular matrix provides mammary epithelial growth and differentiation in vitro. Proc. Natl. Acad. Sci. USA, 79:3213-3217.

Wooding, F.B.P. (1971a) The mechanism of secretion of the milk fat globule. J. Cell Sci, 9:805-821.

Wooding, F.B.P. (1971b) The structure of the milk fat globule membrane. J. Ultrastruct. Res., 37:388-400.

Yanagihara, N., Tachikawa, E., Izumi, F., Yasugawa, S., Yamamoto, H., and Miyamoto, E. (1991) Staurosporine: An effective inhibitor for $\mathrm{Ca} 2+$ calmodulin dependent protein kinase II. J. Neurochem. $56: 294-298$. 